\title{
PENGARUH KOMPENSASI DAN KOMPENTESI DENGAN MOTIVASI SEBAGAI INTERVENING DALAM MENINGKATKAN KINERJA
}

\author{
Meutia, Ika Sari dan Tubagus Ismail \\ Universitas Sultan Ageng Tirtayasa,Universitas Mercubuana \\ Email: tia-almer@yahoo.co.id
}

\begin{abstract}
The objective of this research was to test the impact of system financial and nonfinancial compensation, competency on the employee performance and on the motivation as intervening variable. The research used partial least square method for the hypotesis testing and produced 100 respondent for the sample by using nonprobability samples with the convinience method. The result of the research revealed that the system of financial and nonfinancial compensation have significance impacts on employee performance and motivation but the competency does not significance impacts on employee performance and motivation. However, further result revealed that motivation have significance impacts on employee performance.In order to improve the employee performance, the training is a needed and should be conducted in accordance with the job position. Moreover, the fair compensation with the range not far from the employee expectation.
\end{abstract}

Keywords: Financial Compensation, Compensation Non Financial, Competency, Motivation, Employee Performance

Abstrak: Penelitian ini bertujuan untuk menyelidiki pengaruh kompensasi dan kompetensi yang dapat meningkatkan kinerja pegawai dengan motivasi sebagai variabel intervening. Kompensasi yang digunakan dalam penelitian ini adalah kompensasi finansial dan non finansial. Penelitian ini menggunakan persamaan struktural berbasis varians, smart PLS digunakan untuk memecah permasalahan SEM berbasis varians. Responden dalam penelitian ini adalah 100 pegawai perusahaan manufaktur di Banten. Hasil penelitiannya menemukan bahwa bahwa kompensasi memiliki pengaruh yang signifikan terhadap kinerja. Kompensasi memiliki pengaruh yang signifikan terhadap motivasi. Kompetensi tidak memiliki pengaruh secara signifikan terhadap kinerja. Kompetensi tidak memiliki pengaruh secara signifikan terhadap motivasi. Motivasi memiliki pengaruh yang signifikan terhadap kinerja. Untuk meningkatkan kinerja pegawai, training training diperlukan sesuai dengan posisi pegawai masing masing. Selain itu kompenasasi sebaiknya tidak terlalu jauh dari yang diharapkan oleh pegawai.

Key word: Financial Compensation, Compensation Non Financial, Competency, Motivation, Employee Performance

\section{PENDAHULUAN}

Sumber daya manusia di dalam suatu perusahaan memegang peranan yang sangat penting (Berk dan Berk, 2000). Perusahaan harus mampu membangun dan meningkatkan kinerja di dalam lingkungannya. Salah satu sumber daya ang dimiliki adalah karyawan 
sebagai sumber daya manusia (Babakus dan Mangold, 1992). Pembinaan para karyawan termasuk yang harus diutamakan sebagai aset utama perusahaan. Proses belajar harus menjadi budaya perusahaan sehingga keterampilan para karyawan dapat dipelihara, bahkan dapat ditingkatkan. Dalam hal ini loyalitas karyawan yang kompeten harus diperhatikan (Akao, 1990).

Kompensasi memegang peranan penting dalam meningkatkan kinerja pegawainya, dimana seseorang akan bekerja secara maksimal agar mendapat kompensasi yang sesuai (Antreas dan Opoulos, 2003); Van Herpen dan Van Praag (2005). Karyawan merupakan kekayaan utama bagi perusahaan, dimana mereka akan menjadi perencana, pelaksana dan pengendali yang selalu memberikan peran aktif dalam mewujudkan tujuan perusahaan.

Karyawan mempunyai pikiran, perasaaan dan keinginan yang dapat mempengaruhi sikap-sikapnya terhadap pekerjaan yang dilakukannya (Crostack, 2007). Sikap ini akan menentukan seberapa besar kecintaanya terhadap pekerjaan yang dibebankan kepadanya, loyalitasnya kepada perusahaan dan tentu saja kepuasan kerjanya. Semakin tingginya persaingan sehingga para karyawan dipacu sedemikian rupa sampai melampaui kemampuan fisik dan mentalnya (Bolton dan Drew, 1991). Oleh karena itulah kepuasan kerja karyawan harus selalu dijaga dan dipenuhi sebaik-baiknya oleh pihak perusahaan (Jenab et al., 2014). Sejak dari proses rekrutmen sampai dengan proses evaluasi kinerja, para karyawan harus selalu diingatkan bahwa mereka adalah modal perusahaan, agar para karyawan memahami makna keberadaan mereka di dalam perusahaan (Dickinson, 1995).

Perusahaan yang hebat akan selalu merawat kualitas para karyawannya, apakah itu dari sisi emosi, intelektualitas, ataupun dari sisi keterampilan (Aktar, 2012). Perusahaan yang hebat selalu berupaya untuk menjadikan setiap karyawannya sebagai modal, dan menghindarkan para karyawannya menjadi beban perusahaan. Karyawan yang berkompeten sangat dibutuhkan untuk peningkatan kinerja perusahan, dimana kompetensi merupakan suatu kemampuan untuk melaksanakan atau melakukan suatu pekerjaan yang dilandasi atas keterampilan dan pengetahuan serta di dukung oleh sikap kerja yang dituntut oleh pekerjaan tersebut (John dan Smith, 2014).

Kompensasi yang sesuai juga akan menentukan apakah pegawai akan tetap bertahan bekerja atau keluar dari tempatnya bekerja. Pemberian kompensasi dimaksudkan agar pegawai dapat bekerja secara maksimal sehingga menghasilkan kinerja yang optimal. Selain faktor kompensasi yang perlu di perhatikan adalah motivasi. Adapun indikasi melemahnya motivasi karyawan adalah lemahnya pengawasan, tidak ada penghargaan terhadap target yang dicapai, lingkungan kerja seperti tata kelola ruangan yang kurang memadai sehingga berpengaruh terhadap kinerja karyawan yang kurang optimal.

Pemberian kompensasi untuk meningkatkan motivasi dan kepuasan kerja karyawan (Ismail, 2016). Adanya kompensasi yang memadai dapat membuat karyawan termotivasi untuk bekerja dengan baik, mencapai prestasi seperti yang diharapkan perusahaan, dan dapat meningkatkan tingkat kepuasan karyawan. Kompensasi atau balas jasa umumnya bertujuan untuk kepentingan perusahaan dan karyawan (Ismail, 2016). Kepentingan perusahaan dengan pemberian kompensasi yaitu memperoleh imbalan prestasi kerja yang lebih besar dari karyawan. Sedangkan kepentingan karyawan atas kompensasi yang diterima, yaitu dapat memenuhi kebutuhan dan keinginannya dan menjadi keamanan ekonomi rumah tangganya. Bagi perusahaan, kompensasi merupakan faktor utama dalam kepegawaian. Kebijakan sumber daya manusia banyak berhubungan dengan pertimbangan 
untuk menentukan kompensasi karyawan. Tingkat besar-kecilnya kompensasi sangat berkaitan dengan tingkat pendidikan, tingkat jabatan, dan masa kerja karyawan.

Reward management sistem yang baik akan meningkatkan kinerja karyawan, karyawan akan mengeluarkan sejumlah karyanya jika ia merasa upaya sebelumnya telah menghasilkan imbalan atau penghargaan yang diterimanya. Oleh karena itu, penelitian ini melanjutkan penelitian Cabral (2015) dengan memfokuskan pada sistem kompensasi, kompetensi terhadap kinerja karyawan dimana motivasi sebagai variabel intervening. Penelitian ini berbeda dengan Cabral (2015), pada penelitian Cabral (2015) menguji pengaruh management reward sistem terhadap kinerja karyawan, sedangkan pada penelitian ini menguji sistem kompensasi financial dan nofinancial serta kompetensi terhadap motivasi dan kinerja karyawan. Dimana kompensasi seharusnya berpengaruh terhadap motivasi kerja terlebih dahulu sebelum berpengaruh terhadap kinerja karyawan begitu pula dengan kinerja karyawan tidak hanya dipengaruhi oleh faktor kompensasi saja tetapi kompetensi pun berpengaruh. Oleh karena itu peneliti tertarik untuk melakukan penelitian tersebut untuk memperoleh bukti empiris apakah dengan penambahan variabel, teori yang sama tetapi populasi, waktu dan tempat berbeda diharapkan akan menunjukkan hasil yang berbeda. Tujuan penelitian ini adalah menginvestigasi pengaruh sistem kompensasi financial dan non financial terhadap kinerja karyawan dengan motivasi sebagai variable intervening

\section{KAJIAN TEORI}

Pengaruh Sistem Kompensasi Terhadap Kinerja. Karyawan akan termotivasi untuk mengeluarkan sejumlah besar usaha dalam karyanya jika ia merasa upaya sebelumnya telah menghasilkan imbalan atau penghargaan yang diterimanya (John dan Smith, 2014). Gaji, bonus kinerja, pengakuan dan pujian merupakan alat manajemen yang dapat digunakam untuk memotivasi karyawan berkinerja secara efektif dan efisien (John dan Smith, 2014). Kepuasan gaji mempunyai pengaruh positif terhadap kinerja karyawan (John dan Smith, 2014). Kompensasi berpengaruh positif dan signifikan terhadap motivasi dan kinerja karyawan (John dan Smith, 2014). Penggunaan kompensasi keuangan oleh organisasi berpengaruh $23 \%$ pada kinerja.

Hasil penelitian ini ditunjang oleh penelitian Allen dan Der Velden (2001) menyatakan bahwa kompensasi berpengaruh signifikan dan positif terhadap kinerja. kinerja akan meningkat apabila jumlah kompensasi ditingkatkan. Penelitian lain yang mendukung adalah Akao (1990) menyatakan kompensasi berpengaruh signifikan dan positif terhadap kinerja, yang artinya bahwa kinerja karyawan akan tinggi apabila kompensasi yang diberikan juga tinggi. Penelitian lain yang dilakukan oleh Robinson (2005) mengatakan terdapat hubungan positif diantara kompensasi dengan kinerja. Kompensasi yang diberikan berdasarkan keterampilan karyawan dapat memuaskan karyawan, hal ini menyebabkan karyawan akan semakin meningkatkan kinerjanya agar mendapatkan kompensasi yang semakin tinggi (Allen dan Der Velden, 2001). Kompensasi mempunyai pengaruh paling besar terhadap kinerja karyawan Allen dan Der Velden, 2001. Kompensasi seperti gaji, bonus, insentif, tunjangan, penghargaan dan dana pensiun yang diberikan oleh perusahaan secara adil dan layak dapat meningkatkan kinerja karyawan (Allen dan Der Velden, 2001). 
Selain itu, penelitian ini didukung oleh teori yang dipaparkan oleh Allen dan Der Velden, 2001 kompensasi adalah balas jasa yang diterima karyawan atas hasil kerjanya. Kompensasi yang diberikan diharapkan agar dapat meningkatkan kinerja karyawan dalam melaksanakan tugas dan kewajibannya di dalam perusahaan. Teori lain yang mendukung adalah teori yang dipaparkan oleh Allen dan Der Velden, (2001) yang menyatakan bahwa kompensasi akan diberikan oleh perusahaan kepada karyawan untuk membalas jasa atas pekerjaan yang telah dilakukan oleh karyawan kepada perusahaan. Oleh karena itu dalam penelitian ini diajukan hipotesis pertama sebagai berikut:

H1: Kompensasi berpengaruh terhadap kinerja karyawan.

Pengaruh Sistem Kompensasi terhadap Motivasi Kerja. Karyawan akan termotivasi dengan penghargaan yang diperoleh jika penghargaan tersebut dapat memuaskannya. Penghargaan yang dapat memuaskan karyawan biasanya berkaitan dengan pekerjaan karyawan itu sendiri atau dikenal dengan penghargaan intrinsic. Ada beberapa hal penting yang dapat digunakan sebagai pertimbangan untuk mendistribusikan penghargaan menurut equity theory. Pertama, penghargaan tersebut harus cukup memuaskan kebutuhan dasar manusia. Peraturan pemerintah, perjanjian kerja, dan kejujuran manajerial telah menyediakan penghargaan minimum dalam hampir semua lingkungan kerja. Kedua, karyawan cenderung membandingkan penghargaan yang mereka peroleh dengan penghargaan yang diperoleh karyawan lain. Jika dianggap tidak adil maka akan menimbulkan ketidakpuasan. Oleh karena itu dalam mendistribusikan penghargaan, pihak manajemen harus mempertimbangkan perbedaan individu. Jika tidak dipertimbangkan maka proses pemberian penghargaan akan kurangefektif dari yang diharapkan. Setiap penghargaan harus cukup memuaskan kebutuhan dasar, dianggap adil, diorientasikan secara individual (Van Der Aalst et al.,2003); Stajkovic dan Luthans (2003)

Usaha seorang manager untuk berprestasi ditentukan oleh dua faktor yaitu keyakinan manager terhadap kemungkinan kinerja mendatangkan reward dan nilai reward. Jika seorang manager berkeyakinan bahwa kinerja mempunyai kemungkinan yang tinggi untuk diberi reward, maka hal ini akan mempertinggi usahanya. Sebaliknya, jika kinerja mempunyai kemungkinan kecil untuk mendapatkan reward, maka hal ini akan menurunkan usaha seseorang untuk berprestasi (Lawler dan Porter 1967).

Pujian dan pengakuan merupakan intrinsic reward yang paling efisien yang menambah kinerja karyawan (Van Der Aalst et al.,2003). Intrinsic reward merupakan alat untuk memotivasi karyawan untuk bekerja seperti yang diharapkan (Lawler dan Porter 1967). Oleh karena itu dipenelitian ini diajukan hipotesis kedua sebagai berikut :

$\mathbf{H}_{2}$ : Kompensasi berpengaruh terhadap motivasi kerja.

Pengaruh Kompetensi Terhadap Kinerja Karyawan. Kompentensi dapat dibagi atas dua kategori yaitu "Threshold" dan "Differentiating" (Spencer and Spencer 1993); Vathanophas, dan Thaingam (2007). menurut kriteria yang digunakan untuk memprediksi kinerja suatu pekerjaan. "Threshold competencies adalah karakteristik utama, yang biasanya berupa pengetahuan atau keahlian dasar seperti kemampuan untuk membaca yang harus dimiliki seseorang agar dapat melaksanakan pekerjaannya. Tetapi kategori yang ini tidak untuk menentukan apakah seseorang tersebut berkinerja tinggi atau tidak. Kategori ini jika untuk menilai karyawan hanyalah untuk mengetahui apakah ia mengetahui tugas-tugasnya, bisa mengisi formulir dan lain sebagainya. Sedangkan 
"Differentiating competencies" adalah faktor-faktor yang membedakan individu yang berkinerja tinggi dan rendah. Karena seseorang yang memiliki motivasi yang tinggi maka ia akan mampu menetapkan target atau tujuan yang jauh lebih ketimbang kinerjanya pada tingkat rata-rata.

Kompetensi dikatakan sebagai salah satu faktor yang mempengaruhi kinerja. Kompetensi diperlukan untuk membantu organisasi untuk menciptakan budaya kinerja tinggi. Banyaknya kompetensi yang digunakan oleh sumber daya manusia akan meningkatkan kinerja (Borjas, 1979) Borjas dalam penelitiannya menyimpulkan bahwa kompetensi berpengaruh terhadap kinerja karyawan. Kompetensi mempunyai pengaruh signifikan dan positif terhadap kinerja (Boyatzis, 1982).

Penelitian lain yang mendukung adalah penelitian yang dilakukan oleh Ferrari dan Emiliani (2009) menyatakan bahwa terdapat pengaruh yang signifikan antara kesesuaian kompetensi dengan kinerja. Kompetensi berpengaruh signifikan dan positif terhadap kinerja, berarti apabila kompetensi semakin ditingkatkan maka kinerja pegawai akan semakin meningkat. bahwa untuk mendapatkan kinerja yang efektif pada setiap jabatan, karyawan harus dilengkapi dengan kompetensi yang baik agar kinerja yang dihasilkan memuaskan Ferrari dan Emiliani (2009). Oleh karena itu dipenelitian ini diajukan hipotesis ketiga sebagai berikut :

H3 : Kompetensi berpengaruh terhadap kinerja karyawan.

Pengaruh Kompetensi Terhadap Motivasi. Menurut Bergenhenegouwen (1996). bahwa kompetensi dasar merupakan keterampilan yang luas tentang produksi dan teknologi korporasi yang mendukung organisasi untuk beradaptasi dengan cepat terhadap peluangpeluang yang timbul. Indikator dari kompetensi teknis adalah: (1) Tingkat Pendidikan. Pendidikan merupakan persyaratan tingkat pendidikan yang dibutuhkan dalam memegang jabatan dan biasanya berkaitan dengan tingkat intelektual, serta tingkat pengetahuan yang diperlukan. Pendidikan yang menjadi persyaratan minimal di dalam sebuah organisasi/perusahaan; (2) Pengalaman Kerja. Pengalaman kerja adalah lama seseorang dalam menangani suatu peran atau jabatan tertentu dan melaksanakannya dengan hasil yang baik; (3) Kemampuan Menganalisis. Kemampuan untuk memehami situasi dengan memecahkannya menjadi bagian-bagian yang lebih kecil, atau mengamati implikasi suatu keadaan tahap demi tahap berdasarkan pengalaman masa lalu.

Indikator dari kompetensi non teknis menurut Hutapea dan Nurianna Thoha (2008) adalah: (1) Pengendalian Diri (Self Control). Kemampuan untuk mengendalikan emosi diri agar terhindar dari berbuat sesuatu yang negative saat situasi tidak sesuai harapan atau saat berada dibawah tekanan; (2) Kepercayaan Diri (Self Confidence). Tingkat kepercayaan yang dimilikinya dalam menyelesaikan masalah; (3) Fleksibilitas (Flexibility). Kemampuan untuk beradaptasi dan bekerja secara efektif dalam berbagai situasi, orang atau kelompok; (4) Membangun Hubungan (Relationship Building). Kemampuan bekerja untuk membangun atau memelihara keramahan, hubungan yang hangat atau komunikasi jaringan kerja dengan seseorang, atau mungkin suatu hari berguna dalam mencapai tujuan kerja.

Secara umum, semakin sering suatu kompetensi dipergunakan, justru semakin baik dan semakin bernilai (Boyatzis, 1982). Sementara itu, kompetensi merupakan hal yang paling sulit untuk ditiru, karena sifatnya yang memang berbeda dan spesifik bagi masingmasing individu ((Boyatzis, 1982)). Hal inilah yang mendasari simpulan penelitian 
Munro, yang menyatakan bahwa bagi berbagai industri, kompetensi dipercaya sebagai faktor pemungkin (enabler) organisasi untuk membangun keunggulan bersaingnya dengan cara menyediakan rerangka untuk fungsi-fungsi sumber daya manusia guna diarahkan secara tajam pada aktivitas-aktivitas untuk membangun kapabilitas para pegawainya (Boyatzis, 1982)). Oleh karena itu dipenelitian ini diajukan hipotesis keempat sebagai berikut :

H4: Kompetensi berpengaruh terhadap kinerja karyawan

Pengaruh Motivasi Terhadap Kinerja. Motivasi merupakan sebuah dorongan yang muncul dari dalam diri seseorang yang akan mengarahkan tindakan seseorang untuk mencapai suatu hasil yang diinginkannya. Motivasi sangat mendukung kinerja karyawan seperti produktivitas, dan ketekunan (Gungor, P. 2011). Karyawan akan lebih bertanggung jawab bila ditawarkan kesempatan untuk berkembang. Karyawan yang termotivasi juga lebih bersedia untuk dilibatkan dalam pekerjaan rekan kerja mereka, jika dibandingkan dengan karyawan yang tidak termotivasi (Kavaas dan Dysoik,2009). Seseorang mau berupaya karena ada kebutuhan individualnya agar karyawan termotivasi, perusahaan harus membantu karyawan untuk mencapai tujuan individunya, salahsatunya dengan memenuhi kebutuhan karyawan tersebut.

Motivasi adalah suatu keahlian, dalam mengarahkan pegawai dan organisasi agar mau bekerja secara berhasil sehingga keinginan para pegawai dan tujuan organisasi sekaligus tercapai. Menurut Gungor (2011). motivasi adalah keadaan di mana usaha dan kemauan keras seseorang diarahkan kepada pencapaian hasil-hasil atau tujuan tertentu. Hasil-hasil yang dimaksud bisa berupa produktivitas, kehadiran atau perilaku kerja kreatif lainnya. Motivasi menurut Sajuyigbe, et al., (2013). adalah proses menggerakkan manusia, dan memberikan motivasi artinya proses untuk menggerakkan orang lain agar melakukan sesuatu sebagaimana yang diharapkan oleh penggerakannya atau yang mengarahkannya.

Motivasi seseorang berawal dari kebutuhan, keinginan, dan dorongan untuk bertindak demi tercapainya kebutuhan atau tujuan. Hal ini menandakan kuatnya dorongan, usaha, intensitas dan kesediannya untuk berkorban demi tercapainya tujuan. Semakin kuat dorongan atau motivasi dan semangat akan semakin tinggi usaha atau kinerja yang diberikannya (Ferrari, 2010)

Pemberian dorongan sebagai salah satu cara memotivasi karyawan, penting dilakukan untuk meningkatkan kinerja karyawan sehingga dapat mencapai hasil yang dikehendaki oleh manajemen. Pemberian motivasi kerja yang baik berpengaruh pada meningkatnya kinerja dan optimalnya hasil kerja sesuai dengan standar kerja yang ditetapkan (Ferrari, 2010).

Motivasi merupakan variabel penting, yang perlu mendapat perhatian besar dari organisasi dalam peningkatan kinerja karyawannya. Oleh karena itu dalam penelitian ini diajukan hipotesis ketiga sebagai berikut:

H5: Motivasi berpengaruh terhadap kinerja karyawan

Berdasarkan uraian di atas, maka paper ini merangkainya dalam sebuag figure 1 yang menggambarkan hubungan antar variabel. 


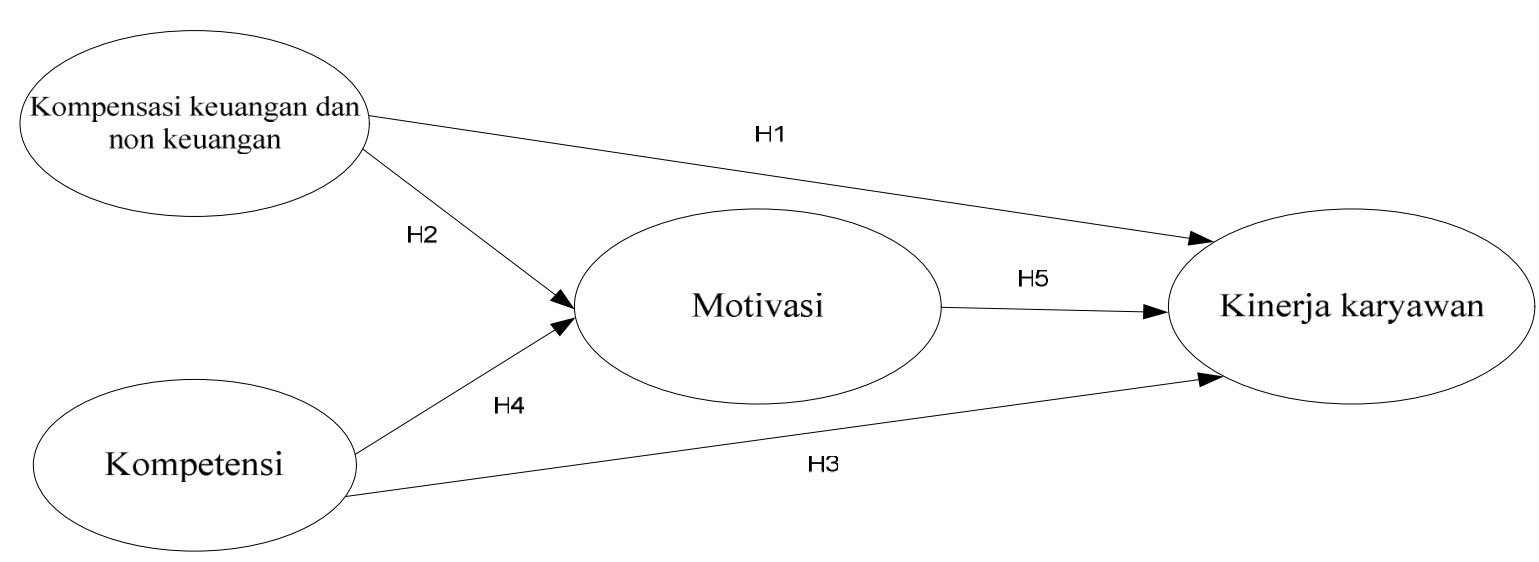

Gambar 1. Model Penelitian

\section{METODE}

Variabel dalam penelitian ini diukur dengan cara responden diminta mengisi dan menjawab pertanyaan didalam kuesioner yang diberikan. Dalam penelitian ini digunakan dua jenis skala pengukuran, yaitu: skala Interval digunakan untuk mengukur variabel dependen, independen, dan intervening, yaitu kompensasi, kompetensi dan kinerja dengan menggunakan skor $1 \mathrm{~s} / \mathrm{d} 5$ (tidak setuju 12345 sangat setuju). Teknik pengumpulan data dilakukan dengan teknik survei langsung ke pegawai perusahaan manufaktur di Propinsi Banten. Survei dilakukan dengan rentang waktu bulan November 2015 sampai dengan Januari 2016. Analisa data dalam penelitian ini menggunakan Partial Least Square (PLS). Analisa data dalam penelitian ini menggunakan Partial Least Square (PLS). PLS dapat digunakan pada setiap jenis skala data (nominal, ordinal,interval,dan rasio) serta syarat asumsi yang lebih fleksibel. PLS juga digunakan untuk mengukur pengaruh setiap indikator dengan konstruknya. Selain itu, dalam PLS dapat dilakukan uji bootstrapping terhadap structural model yang bersifat outer model dan inner model. Karena dalam penelitian ini menggunakan indikator untuk mengukur setiap konstruknya, dan juga model pengukuran bersifat structural, maka dipilih menggunakan PLS.

PLS dapat digunakan untuk tujuan konfirmasi, seperti pengujian hipotesis dan tujuan eksplorasi. Tetapi PLS lebih mengutamakan sebagai eksplorasi bukan konfirmasi. Namun tujuan utama dari PLS adalah untuk menjelaskan hubungan antar konstruk dan menekankan pengertian tentang nilai hubungan tersebut. Dalam hal ini, hal penting yang harus diperhatikan adalah keharusan adanya teori yang memberikan asumsi untuk menggambarkan model, pemilihan variabel, pendekatan analisis dan interpretasi hasil. Penelitian ini bertujuan untuk menguji pengaruh antar konstruk (sistem kompensasi financial dan non financial, kompetensi, motivasi dan kinerja) serta untuk memahami pengertian ketiga konstruk tersebut. Dan juga karena dibutuhkannya indkator dalam penelitian ini, serta model pengukuran bersifat structural maka penelitian ini menggunakan Partial Least Square (PLS).Setiap konstruk diukur oleh indikator yang diringkas pada tabel 1.

Kuesioner penelitian ini terdiri dari dua bagian. Bagian pertama meliputi pertanyaan sosiodemografi termasuk jenis kelamin, usia, status perkawinan, tingkat pendidikan, 
jabatan dan masa kerja. Pada bagian kedua terdapat 29 pertanyaan yang menentukan pilihan karyawan tentang alat sistem kompensasi,kompetensi, motivasi dan kinerja karyawan. Pertanyaan kuesioner penelitian ini diadaptasi dari penelitian yang dilakukan

\section{HASIL DAN PEMBAHASAN}

Hasil dari uji indikator semuanya valid hal ini terlihat dari nilai signifikansi dari nilai $\mathrm{T}$ statistik semuanya di atas 1.96. Berdasarakan statistik deskrptif jumlah responden dengan jenis kelamin laki-laki berjumlah 76 responden $(76 \%)$ dan jumlah responden dengan jenis kelamin perempuan sebanyak 24 responden (24\%). Responden kurang dari 30 tahun sebanyak 44 responden (44\%), responden berusia $30-40$ tahun berjumlah 27 responden $(27 \%)$ dan responden yang berusia diatas 40 tahun berjumlah 29 responden $(29 \%)$.

Alasan untuk mengajukan pertanyaan sosiodemografi adalah untuk menganalisis tingkat respon rata-rata karyawan sesuai dengan usia dan tingkat pendidikan, selain itu marital status, jabatan dan masa kerja dari responden yang diperlukan untuk validitas jawaban.

Responden yang menempuh pendidikan terakhir SMP sebanyak 43 responden (43\%), responden yang menempuh pendidikan terakhir SMU sebanyak 11 responden (11\%) yang merupakan responden mayoritas, responden yang menempuh pendidikan S1 sebanyak 36 responden (36\%) dan responden yang menmpuh pendidikan S2 sebanyak 10 responden $(10 \%)$. Responden terbanyak adalah responden yang memiliki masa kerja selama 5-10 tahun sebanyak 66 responden $(66 \%)$, responden yang masa kerjanya kurang dari 5 tahun sebanyak 12 responden (12\%), masa kerja 10-15 tahun sebanyak 14 responden $(14 \%)$ dan sedikit responden yang masa kerjanya lebih dari 15 tahun yaitu sebanyak 8 responden $(8 \%)$.

Responden dalam penelitian ini memiliki proporsi dengan posisi Manager 10 responden (10\%), posisi Kepala Outlet 4 responden (4\%), posisi Accounting 8 responden (8\%), posisi administrasi 18 responden (18\%), posisi Sopir dan kenek 16 responden $(16 \%)$, posisi Collector 8 responden (8\%), posisi Tukang potong 36 responden (36\%).

Responden terbanyak adalah responden yang sudah menikah sebanyak 74 responden (74\%) dan responden belum menikah sebanyak 26 responden $(26 \%)$.

Penelitian ini untuk menguji hipotesis yang diajukan dengan menggunakan metode Partial Least Square (PLS). Dalam analisis dengan PLS terdapat dua tahap pengujian, yaitu analisis outer model atau measurement model dan pengujian inner model atau structural model.

Pengujian outer model terdapat 3 (tiga) kriteria yaitu convergent validity, discriminant validity dan composite reliability. Pengujian outer model dilakukan agar alat ukur memenuhi syarat dan dapat secara tepat dan akurat mengukur apa yang seharusnya diukur. Convergent validity digunakan untuk menyakinkan bahwa indikator-indikator yang digunakan mampu mengukur dengan tepat dimensi atau konstruk yang mau diukur. Discriminant validity digunakan untuk menguji apakah indikator-indikator suatu konstruk tidak berkorelasi tinggi dengan indikator dari konstruk lain. 
Meutia, Sari dan Ismail: Pengaruh Kompensasi dan Kompentensi dengan Motivasi...

Tabel 1. Outer Loading Uji Convergent Validity

\begin{tabular}{|c|c|c|c|c|c|c|}
\hline Konstruk & Dimensi & Indikator & $\begin{array}{l}\text { original } \\
\text { sample } \\
\text { estimate }\end{array}$ & $\begin{array}{c}\text { mean of } \\
\text { subsamples }\end{array}$ & $\begin{array}{l}\text { Standard } \\
\text { deviation }\end{array}$ & T-Statistic \\
\hline \multirow{7}{*}{ Compensation } & \multirow{4}{*}{$\begin{array}{l}\text { Financial } \\
\text { Compensation }\end{array}$} & $\mathrm{FC} 1$ & 0.616 & 0.613 & 0.116 & 5.322 \\
\hline & & $\mathrm{FC} 4$ & 0.664 & 0.674 & 0.123 & 5.379 \\
\hline & & FC5 & 0.703 & 0.692 & 0.105 & 6.675 \\
\hline & & FC6 & 0.812 & 0.834 & 0.07 & 11.658 \\
\hline & \multirow{3}{*}{$\begin{array}{l}\text { NonFinancial } \\
\text { Compensation }\end{array}$} & NFC1 & 0.714 & 0.707 & 0.142 & 5.038 \\
\hline & & NFC2 & 0.536 & 0.534 & 0.185 & 2.902 \\
\hline & & NFC3 & 0.74 & 0.722 & 0.108 & 6.875 \\
\hline \multirow{6}{*}{ Competency } & \multirow{2}{*}{ Konsep Diri } & KD1 & 0.878 & 0.879 & 0.041 & 21.523 \\
\hline & & KD2 & 0.929 & 0.924 & 0.028 & 32.887 \\
\hline & \multirow{2}{*}{ Keterampilan } & Ktr1 & 0.94 & 0.94 & 0.022 & 42.914 \\
\hline & & $\mathrm{Ktr} 2$ & 0.915 & 0.913 & 0.052 & 17.516 \\
\hline & \multirow{3}{*}{ Pengetahuan } & $\mathrm{P} 1$ & 0.966 & 0.964 & 0.013 & 75.701 \\
\hline & & $\mathrm{P} 2$ & 0.956 & 0.956 & 0.019 & 49.969 \\
\hline \multirow{3}{*}{ Kinerja } & & K1 & 0.856 & 0.844 & 0.057 & 14.954 \\
\hline & & $\mathrm{K} 2$ & 0.939 & 0.943 & 0.029 & 32.395 \\
\hline & & $\mathrm{K} 3$ & 0.86 & 0.859 & 0.079 & 10.859 \\
\hline \multirow{9}{*}{ Motivasi } & \multirow{6}{*}{$\begin{array}{l}\text { Motivasi } \\
\text { Ekstrinsik }\end{array}$} & ME1 & 0.498 & 0.483 & 0.163 & 3.058 \\
\hline & & ME2 & 0.65 & 0.653 & 0.117 & 5.54 \\
\hline & & ME3 & 0.815 & 0.815 & 0.092 & 8.845 \\
\hline & & ME4 & 0.705 & 0.715 & 0.147 & 4.809 \\
\hline & & ME5 & 0.912 & 0.914 & 0.034 & 27.057 \\
\hline & & MI1 & 0.536 & 0.553 & 0.115 & 4.649 \\
\hline & \multirow{3}{*}{$\begin{array}{l}\text { Motivasi } \\
\text { Instrinsik }\end{array}$} & MI2 & 0.742 & 0.751 & 0.102 & 7.281 \\
\hline & & MI3 & 0.621 & 0.626 & 0.106 & 5.85 \\
\hline & & MI4 & 0.659 & 0.656 & 0.108 & 6.131 \\
\hline
\end{tabular}

Sumber: Output SmartPLS

Discriminant validity juga dapat dinilai dengan melihat nilai average variance extracted. Nilai AVE menunjukkan kemampuan nilai variabel laten dalam mewakili skor data asli. Cut-off value AVE yang digunakan adalah $>0,5$. Jika nilai AVE indentik dengan multiple $\mathrm{R}^{2}$ koefisien determinasi), maka akar AVE identic dengan multiple $\mathrm{R}$ (koefisien regresi berganda) pada analisis regresi. Hasil average variance extracted dapat dilihat pada Tabel 2.

Hasil output diatas merupakan hasil uji unidimensional dari masing-masing konstruk dengan melihat indikator konstruknya. Indikator dikatakan mempunyai reliabilitas yang baik jika nilainya lebih dari 0,7 , sedangkan loading factor 0,5 sampai 0,6 masih dapat dipertahankan. Berdasarkan kriteria tersebut, indikator yang nilai loading factornya kurang dari 0,5 harus dieliminasi dari analisis.

Tabel 2. Average Variance Extracted (AVE) 


\section{Average Variance Extracted (AVE)}

\section{Kompensasi}

Kompensasi financial

0.794

Kompensasi

Nonfinancial

0.748

Kompetensi

Konsep Diri

0.90

Keterampilan

0.946

Pengetahuan

0.949

Motivasi

Ekstrinsik

0.594

Intrinsik

0.517

Kinerja

0.784

Tabel 3. Cross Loading untuk Uji Discriminant Validity

\begin{tabular}{|c|c|c|c|c|c|c|c|c|c|}
\hline Konstruk & Indikator & $\begin{array}{c}\text { Financial } \\
\text { Compens } \\
\text { ation }\end{array}$ & $\begin{array}{c}\text { NonFinan } \\
\text { cial } \\
\text { Compensa } \\
\text { tion } \\
\end{array}$ & $\begin{array}{l}\text { Kons } \\
\text { ep } \\
\text { Diri }\end{array}$ & $\begin{array}{c}\text { Keteram } \\
\text { pilan }\end{array}$ & $\begin{array}{c}\text { Pengeta } \\
\text { huan }\end{array}$ & $\begin{array}{c}\text { Kiner } \\
\text { ja }\end{array}$ & $\begin{array}{c}\text { Motivas } \\
\text { i } \\
\text { Ekstrins } \\
\text { ik } \\
\end{array}$ & $\begin{array}{c}\text { Moti } \\
\text { vasi } \\
\text { Intrin } \\
\text { sik } \\
\end{array}$ \\
\hline \multirow{7}{*}{$\begin{array}{l}\text { Compens } \\
\text { ation }\end{array}$} & FC1 & 0,557 & 0,407 & 0,446 & 0.494 & 0.472 & 0.117 & 0.388 & 0.377 \\
\hline & FC4 & 0,575 & 0,404 & 0,162 & 0.146 & 0.163 & 0.263 & 0.223 & 0.273 \\
\hline & FC5 & 0,658 & 0,392 & 0,218 & 0.229 & 0.194 & 0.136 & 0.376 & 0.445 \\
\hline & FC6 & 0,811 & 0,459 & 0,268 & 0.274 & 0.298 & 0.151 & 0.486 & 0,442 \\
\hline & NFC1 & 0,512 & 0.827 & 0.278 & 0.287 & 0.275 & 0.113 & 0.488 & 0.427 \\
\hline & $\mathrm{NFC} 2$ & 0,561 & 0,536 & 0.384 & 0.417 & 0.36 & 0.248 & 0.543 & 0.469 \\
\hline & $\mathrm{NFC3}$ & 0,507 & 0,588 & 0.247 & 0.217 & 0.254 & 0.16 & 0.499 & 0.671 \\
\hline \multirow{6}{*}{$\begin{array}{c}\text { Competen } \\
c y\end{array}$} & KD1 & 0.437 & 0.374 & 1.072 & 0.826 & 0.957 & 0.234 & 0.582 & 0.464 \\
\hline & KD2 & 0.424 & 0.384 & 1.07 & 0.916 & 1.022 & 0.091 & 0.362 & 0.42 \\
\hline & Ktr1 & 0.474 & 0.435 & 0.934 & 1.069 & 1.031 & 0.041 & 0.374 & 0.467 \\
\hline & Ktr2 & 0.457 & 0.383 & 0.942 & 1.137 & 1.059 & 0.086 & 0.466 & 0.514 \\
\hline & $\mathrm{P} 1$ & 0.45 & 0.357 & 1.104 & 1.023 & 1.152 & 0.166 & 0.45 & 0.441 \\
\hline & P2 & 0.501 & 0.454 & 1.051 & 1.092 & 1.178 & 0.057 & 0.463 & 0.565 \\
\hline \multirow{3}{*}{ Kinerja } & $\mathrm{K} 1$ & 0.238 & 0.217 & 0.197 & 0.084 & 0.135 & 0.856 & 0.444 & 0.545 \\
\hline & K2 & 0.188 & 0.144 & 0.077 & -0.007 & 0.022 & 0.939 & 0.542 & 0.419 \\
\hline & K3 & 0.163 & 0.134 & 0.077 & 0.046 & 0.069 & 0.86 & 0.432 & 0.297 \\
\hline \multirow{7}{*}{ Motivasi } & ME1 & 0.295 & 0.354 & 0.131 & 0.118 & 0.084 & 0.233 & 0.828 & 0.441 \\
\hline & ME2 & 0.379 & 0.406 & 0.278 & 0.188 & 0.236 & 0.318 & 0.894 & 0.669 \\
\hline & ME3 & 0.294 & 0.283 & 0.181 & 0.173 & 0.165 & 0.331 & 0.973 & 0.719 \\
\hline & ME4 & 0.255 & 0.263 & 0.269 & 0.222 & 0.253 & 0.283 & 0.996 & 0.598 \\
\hline & ME5 & 0.403 & 0.376 & 0.298 & 0.249 & 0.277 & 0.334 & 0.863 & 0.685 \\
\hline & MI1 & 0.389 & 0.305 & 0.309 & 0.401 & 0.399 & 0.3 & 0.654 & 0.88 \\
\hline & MI2 & 0.304 & 0.293 & 0.191 & 0.129 & 0.154 & 0.307 & 0.737 & 0.992 \\
\hline
\end{tabular}


Meutia, Sari dan Ismail: Pengaruh Kompensasi dan Kompentensi dengan Motivasi...

\begin{tabular}{lllllllll}
\hline MI3 & 0.367 & 0.342 & 0.2 & 0.276 & 0.218 & 0.316 & 0.664 & 0.978 \\
\hline
\end{tabular}

Sumber: Output SmartPLS

Selain uji validitas konstruk, dilakukan juga uji reliabilitas konstruk, konstruk dinyatakan reliable jika nilai composite reliability diatas 0,7 . Uji reliabilitas berkaitan digunakan untuk menilai akurasi dan konsistensi hasil ukur. Variabel kompensasi mempunyai nilai composite reliability sebesar 0,819 adalah reliable. Variabel kompetensi mempunyai nilai composite reliability sebesar 0,975 adalah reliable. Variabel motivasi mempunyai nilai composite reliability sebesar 0,890 adalah reliable. Variabel kinerja mempunyai nilai composite reliability sebesar 0,916 adalah reliable. Pada hasil composite reliability semua konstruk (variabel) nilainya $>0,7$ maka konstruk (variabel laten) adalah reliable atau memiliki realibilitas yang baik (Tabel. 1).

Penelitian ini menggunakan pengujian inner model yaitu menguji kelayakan model (goodness of fit). Dari inner model diketahui terdapat satu variabel terikat yaitu kinerja karyawan (K) dan satu variabel intervening yaitu motivasi (M). Nilai R-square untuk variabel kinerja adalah 0,310 atau $31,0 \%$ yang berarti bahwa variabel kinerja mampu menjelaskan informasi yang terkandung dalam data asli sebesar 31,0\% sedangkan sisanya sebesar $69,0 \%$ dijelaskan oleh variabel lain di luar model penelitian dan variabel error. Nilai koefisien determinasi motivasi adalah sebesar 0,327 atau $32,7 \%$ yang berarti bahwa variabel motivasi mampu menjelaskan informasi yang terkandung dalam data asli sebesar $32,7 \%$ sedangkan sisanya $67,3 \%$ dijelaskan oleh variabel lain di luar model penelitian dan variabel error.

Tabel 4. Result for Inner Weight

\begin{tabular}{lcccc}
\hline & $\begin{array}{c}\text { original sample } \\
\text { estimate }\end{array}$ & $\begin{array}{c}\text { mean of } \\
\text { subsamples }\end{array}$ & $\begin{array}{c}\text { Standard } \\
\text { deviation }\end{array}$ & T-Statistic \\
\hline $\begin{array}{l}\text { Kompensasi -> } \\
\text { Kinerja }\end{array}$ & 0.350 & 0,370 & 0.144 & 2,524 \\
$\begin{array}{l}\text { Kompensasi -> } \\
\text { Motivasi }\end{array}$ & 0.493 & 0.529 & 0.153 & 3.231 \\
$\begin{array}{l}\text { Kompetensi -> } \\
\text { Kinerja }\end{array}$ & -0.096 & -0.075 & 0.148 & 0.644 \\
$\begin{array}{l}\text { Kompetensi -> } \\
\text { Motivasi }\end{array}$ & 0.143 & 0.123 & 0.132 & 1.078 \\
Motivasi -> Kinerja & 0.566 & 0.563 & 0.145 & 3.892 \\
\hline Sumber: Output SmatPLS, 2016 & & &
\end{tabular}

Sumber: Output SmartPLS, 2016

Berdasarkan Tabel 4. Terdapat lima (5) hipotesis dalam penelitian ini. Pengujian hipotesis pada PLS, pada dasarnya adalah menguji signifikansi koefisien jalur yang ada pada model. Untuk menyimpulkan apakah jalur atau hipotesis penelitian terbukti, digunakan cut-off value nilai t-hitung $=1,96$, maka hipotesis penelitian terbukti (hipotesis diterima).

Berdasarkan hasil uji hipotesis disimpulkan hipotesis pertama memiliki hubungan yang positif dan berpengaruh signifikan sehingga hipotesis pertama diterima, karena nilai original sample estimate 0,368 (positif) dan nilai t-statistik 2,552 >1,96 (signifikan). 
Hasil ini berarti kompensasi memiliki pengaruh positif dan signifikan terhadap kinerja karyawan. Berdasarkan hasil uji hipotesis disimpulkan bahwa hipotesis kedua memiliki hubungan positif dan berpengaruh signifikan sehingga hipotesis kedua diterima, karena nilai original sample estimate sebesar 0,493 (positif) dan t-statistic sebesar 3,231>1,96 (signifikan). Hasil ini berarti kompensasi yang memiliki pengaruh positif dan signifikan terhadap motivasi. Hipotesis kedua diterima, menunjukkan bahwa kompensasi yang diberikan kepada karyawan memiliki pengaruh yang signifikan pada motivasi kerja karyawan. Hasil uji potesis ketiga memiliki hubungan negative dan tidak berpengaruh secara signifikan sehingga hipotesis ketiga ditolak, karena original sample estimate sebesar -0,096 (negatif) dan nilai t- statistic sebesar 0,644 < 1,96 (tidak signifikan). Hasil ini berarti kompetensi tidak berpengaruh signifikan terhadap kinerja karyawan.

Tabel 5. Uji Sobel

\begin{tabular}{lcccc}
\hline & $\begin{array}{c}\text { Orig. sample } \\
\text { estimate }\end{array}$ & $\begin{array}{c}\text { Standard } \\
\text { error }\end{array}$ & Indirect effect & Direct Effect \\
\hline $\begin{array}{l}\text { Kompensasi }> \\
\text { Motivasi }\end{array}$ & 0.493 & 0.529 & 0.006 & 0.01 \\
Kompetensi $>$ Motivasi & 0.143 & 0.132 & 0.14 & 0.29 \\
\hline
\end{tabular}

Sumber: output sobel test, 2016

Hipotesis keempat memiliki hubungan positif dan tidak berpengaruh secara signifikan sehingga hipotesis keempat ditolak, karena nilai original estimate sebesar 0,143 (positif) dan nilai t- statistic sebesar 1,078 < 1,96 (tidak signifikan). Hasil ini berarti kompetensi tidak berpengaruh signifikan terhadap motivasi karyawan. Berdasarkan hasil uji hipotesis disimpulkan bahwa hipotesis kelima memiliki hubungan positif dan berpengaruh signifikan sehingga hipotesis kelima diterima, karena nilai original estimate sebesar 0,566 (positif) dan nilai t-statistik sebesar 3,892>1,96 (signifikan). Hasil ini berarti motivasi berpengaruh signifikan terhadap kinerja karyawan.

Uji sobel dilakukan untuk menguji signifikansi variabel intervening sebagai variabel mediasi antara variabel independen dan dependen. Untuk menyimpulkan hasil uji sobel bahwa variabel intervening terbukti siginifikan adalah nilai pvalue $<0.05$, yang berarti variabel intervening berpengaruh menjadi mediasi antara variabel independen dan dependen). Hasil pengujian sobel disajikan pada Tabel 4.

Berdasarkan Table 4. hasil uji sobel menunjukkan bahwa indirect effect pada variabel kompensasi nilainya 0.006 dimana nilainya $<$ pvalue $(0.05)$ maka indirect effect dari motivasi terhadap kompensasi adalah signifikan, sehingga motivasi secara tidak langsung berpengaruh secara signifikan memediasi variabel kompensasi terhadap kinerja.

Direct effect pada variabel kompensasi nilainya 0.01 dimana nilainya $<$ pvalue $(0.05)$ maka direct effect dari motivasi terhadap kompensasi adalah signifikan, sehingga motivasi secara langsung berpengaruh secara signifikan memediasi variabel kompensasi terhadap kinerja.

Berdasarkan Table 5. hasil uji sobel menunjukkan bahwa indirect effect pada variabel kompetensi nilainya 0.14 dimana nilainya $>$ pvalue $(0.05)$ maka indirect effect dari motivasi terhadap kompetensi adalah tidak signifikan, sehingga motivasi secara tidak 
langsung tidak berpengaruh secara signifikan memediasi variabel kompetensi terhadap kinerja.

Direct effect pada variabel kompetensi nilainya 0.29 dimana nilainya $>$ pvalue $(0.05)$ maka direct effect dari motivasi terhadap kompetensi adalah tidak signifikan, sehingga motivasi secara langsung tidak berpengaruh secara signifikan memediasi variabel kompetensi terhadap kinerja.

Hasil pengujian dari hipotesis pertama adalah $\mathrm{H}_{1}$ diterima, hal ini menunjukkan bahwa kompensasi yang diberikan kepada karyawan memiliki pengaruh yang positif dan signifikan terhadap kinerja karyawan ini berarti semakin tinggi perusahaan memberikan kompensasi kepada karyawannya maka semakin tinggi pula kinerja karyawan tersebut. Hal ini sejalan dengan equity theory yang menyatakan bahwa keadilan dalam pemberian kompensasi cenderung menghasilkan kinerja yang tinggi dari para karyawannya. Karyawan yang menerima tambahan kompensasi baik itu kenaikan gaji, bonus, komisi dan penghargaan akan bekerja lebih baik. Karyawan melihat produktifitas yang tinggi sebagai jalan untuk mencapai tujuan pribadinya sehingga menghasilkan kinerja yang tinggi. Sistem kompensasi yang berlaku dalam suatu perusahaan berpengaruh terhadap kinerja karyawan karena sistem kompensasi merupakan suatu sistem atau program yang dilakukan oleh manajemen dengan memberikan tambahan penerimaan bagi karyawan sebagai upaya untuk lebih meningkatkan kinerjanya.

Penelitian ini didukung oleh teori yang dipaparkan oleh (Ferrari, 2010) kompensasi adalah balas jasa yang diterima karyawan atas hasil kerjanya. Kompensasi akan diberikan oleh perusahaan kepada karyawan untuk membalas jasa atas pekerjaan yang telah dilakukan oleh karyawan kepada perusahaan (Ferrari dan Emiliani, 2009).

Hasil penelitian ini konsisten dengan penelitian yang dilakukan (Ferrari, 2010) menyatakan bahwa kompensasi berpengaruh signifikan dan positif terhadap kinerja. kinerja akan meningkat apabila jumlah kompensasi ditingkatkan. Kompensasi berpengaruh signifikan dan positif terhadap kinerja, yang artinya bahwa kinerja karyawan akan tinggi apabila kompensasi yang diberikan juga tinggi (Ferrari, 2010). Hubungan positif diantara kompensasi dengan kinerja. Penelitian yang dilakukan oleh (Vergidis et al.,2008) menyatakan bahwa kompensasi yang diberikan berdasarkan keterampilan karyawan dapat memuaskan karyawan, hal ini menyebabkan karyawan akan semakin meningkatkan kinerjanya agar mendapatkan kompensasi yang semakin tinggi. Penelitian lain yang dilakukan oleh (Vergidis et al.,2008) mengatakan salah satu faktor yang mempengaruhi kinerja adalah kompensasi.

Hasil pengujian dari hipotesis kedua adalah $\mathrm{H}_{2}$ diterima, hal ini menunjukkan bahwa kompensasi yang diberikan perusahaan kepada karyawannya berpengaruh terhadap peningkatan motivasi kerja karyawan. Hal ini sejalan dengan agency theory, dimana memotivasi agen untuk bertindak sesuai dengan kepentingan principal, maka perlu ditetapkan sistem kompensasi demi keselarasan kepentingan principal dan agen.

Karyawan akan termotivasi dengan penghargaan yang diperoleh jika penghargaan tersebut dapat memuaskannya. Penghargaan yang dapat memuaskan karyawan biasanya berkaitan dengan pekerjaan karyawan itu sendiri Hasil penelitian ini konsisten dengan penelitian yang dilakukan oleh Vernadat et al. (2013) yang menyatakan bahwa kompensasi efektif dalam memotivasi karyawan.

Hasil pengujian dari hipotesis ketiga adalah $\mathrm{H}_{3}$ ditolak, yang berarti kompetensi tidak berpengaruh terhadap kinerja. Kompetensi dengan dimensi konsep diri, pengetahuan 
dan ketrampilan tidak berpengaruh secara signifikan terhadap kinerja karyawan yang diharapkan perusahaan. Seharusnya kompetensi diperlukan untuk membantu organisasi untuk menciptakan budaya kinerja tinggi. Banyaknya kompetensi yang digunakan oleh sumber daya manusia akan meningkatkan kinerja (Vom Brocke et al., 2014).

Hasil penelitian ini tidak konsisten dengan hasil penelitian yang dilakukan oleh Wang et al., (2009) yang menunjukkan kompetensi berpengaruh signifikan terhadap peningkatan kinerja karyawan. Kompetensi berpengaruh signifikan dan positif terhadap kinerja, berarti apabila kompetensi semakin ditingkatkan maka kinerja pegawai akan semakin meningkat. Penelitian yang dilakukan oleh Zhao et al., (2105) bahwa untuk mendapatkan kinerja yang efektif pada setiap jabatan, karyawan harus dilengkapi dengan kompetensi yang baik agar kinerja yang dihasilkan memuaskan.

Kompetensi dengan dimensi konsep diri, pengetahuan dan ketrampilan tidak berpengaruh secara signifikan terhadap motivasi karyawan. Sementara itu, kompetensi merupakan hal yang paling sulit untuk ditiru, karena sifatnya yang memang berbeda dan spesifik bagi masing-masing individu

Kompetensi dipercaya sebagai faktor pemungkin (enabler) organisasi untuk membangun keunggulan bersaingnya dengan cara menyediakan rerangka untuk fungsifungsi sumber daya manusia guna diarahkan secara tajam pada aktivitas-aktivitas untuk membangun kapabilitas para pegawainya

Hasil pengujian dari hipotesis kelima adalah $\mathrm{H}_{5}$ diterima, yang berarti motivasi berpengaruh terhadap kinerja karyawan dimana semakin tinggi motivasi kerja karyawan maka kinerjanya akan semakin tinggi pula. Hasil penelitian ini membuktikan bahwa motivasi kerja berpengaruh signifikan terhadap kinerja karyawan, yang berarti bahwa motivasi kerja memang sangat diperlukan karyawan untuk mencapai kinerja yang tinggi.

Hal ini sejalan dengan expectancy theory yang menyatakan bahwa karyawan akan termotivasi untuk melakukan usaha yang optimal apabila mereka merasa bahwa ada hubungan yang kuat antara usaha dan kinerja, kinerja dan penghargaan, serta penghargaan dan pemenuhan tujuan pribadi. Motivasi merupakan usaha dan keinginan yang mempengaruhi kegiatan karyawan tersebut dalam memanfaatkan kemampuan yang mereka miliki untuk menyelesaikan pekerjaannya.

\section{PENUTUP}

Simpulan. Berdasarkan hasil pengujian pada penelitian ini maka dapat di simpulkan bahwa kompensasi memiliki pengaruh yang signifikan terhadap kinerja, hal ini menunjukkan bahwa jika perusahaan memberikan kompensasi yang adil dan tidak jauh berbeda dengan yang diharapkan oleh karyawan maka karyawan akan merasa puas, dan kepuasan akan memicu karyawan untuk terus meningkatkan kinerjanya, sehingga tujuan perusahaan maupun kebutuhan karyawan akan tercapai secara bersamaan. Sebaliknya jika perusahaan memberikan kompensasi yang tidak adil dan jauh berbeda dari harapan karyawan maka karyawan akan cenderung memberikan kinerja yang rendah.

Kompensasi memiliki pengaruh yang signifikan terhadap motivasi, hal ini menunjukkan bahwa jika perusahaan memberikan kompensasi yang adil dan tidak jauh dari pengharapan karyawan maka karyawan akan merasa puas. Rasa puas yang dirasakan oleh karyawan akan cenderung meningkatkan motivasi karyawan untuk lebih meningkatkan kinerjanya. Hal ini disebabkan karena karyawan yang selalu berusaha untuk 
meningkatkan kinerja dan keterampilannya akan mendapatkan kompensasi yang semakin besar. Sebaliknya jika karyawan yang merasa tidak puas atas kompensasi yang diberikan oleh perusahaan maka karyawan motivasi karyawan akan cenderung menurun sehingga kinerja karyawan otomatis akan menurun pula.

Kompetensi tidak memiliki pengaruh secara signifikan terhadap kinerja, hal ini menunjukkan bahwa kompetensi yang rendah yang dimiliki oleh karyawan ternyata bisa mendorong karyawan untuk bisa melakukan usaha yang lebih baik untuk meningkatkan kinerjanya. Hasil penelitian ini berarti semakin tinggi kompetensi seseorang belum tentu bisa meningkatkan kinerja karyawan tersebut.

Kompetensi tidak memiliki pengaruh secara signifikan terhadap motivasi, hal ini menunjukkan bahwa kompetensi yang rendah yang dimiliki karyawan ternyata bisa meningkatkan motivasi karyawan untuk menjadi lebih baik dalam menjalankan pekerjaannya sehari-sehari untuk bisa memenuhi kebutuhan hidupnya. Hasil penelitian ini berarti semakin tinggi kompetensi seseorang belum tentu bisa meningkatkan motivasi karyawan untuk bekerja lebih baik.

Motivasi memiliki pengaruh yang signifikan terhadap kinerja, hal ini menunjukkan bahwa karyawan yang memiliki motivasi yang tinggi cenderung selalu berusaha untuk meningkatkan kinerjanya. Sebaliknya jika karyawan yang memiliki motivasi yang rendah maka karyawan cenderung menghasilkan kinerja yang kurang baik juga.

\section{DAFTAR RUJUKAN}

Aktar, Serena. (2012) The Impact of Rewards on Employee Performance in Commercial Banks of Bangladesh: An Empirical Study. IOSR Journal of Business and Management, 6(2), pp: 9-15

Allen J. E V, Der Velden R. (2001) Educational mismatches versus skill mismatches: effects on wages, job satisfaction, and on-the-job search', "Oxford Economic Papers", 3, 434-452.

Akao, Y. (1990) Quality Function Deployment: Integrating Customer Requirements into Product Design ,Productivity Press, Cambridge, MA.

Antreas, D. and Opoulos, A. (2003) "Modeling customer satisfaction in telecommunication", Production and Operation Management, 12 (2): 224-245.

Babakus, E. and Mangold, W. (1992), "Adapting the SERVQUAL scale to hospital services”, Health Services Research, 26 (6): 767-788.

Bergenhenegouwen,G.J. 1996) "Competence Development - A Challenge for HRM Profssionals: Core Competences of Organizations as Guidelines for The Development of Employees". Journal of European Industrial Training, 20 (9): 29 - 35

Berk, J. and Berk, S. (2000), Quality Management for the Technology Sector, Newnes, Boston, MA.

Borjas G. (1979) "Job satisfaction, wages and unions, "Journal of Human Resources, XIV, pp.21- 40 .

Bolton, R. and Drew, J. (1991) "A longitudinal analysis of the impact of service changes on customer attitudes", Journal of Marketing , 55 (1): 1-10

Boyatzis R. (1982) The competent manager: a model for effective performance, Wiley \& Sons, New York 
Cabral Vieira J.A (2015) Skill mismatches and job satisfaction. Economics Letters Vol. 89, pp. 39- 47

Crostack, H. (2007) "Investigations into more exact weightings of customer demands in QFD", Asian Journal on Quality, 8 (3): 71-80.

Dickinson, B. (1995), "QFD: setting up for success", World Class Design to Manufacture, Vol. 2 No. 5, pp.43-45.

Jenab, K. , Pourmohammadi, H. and Sarfaraz, M. (2014) “An i-AHP \& QFD warranty model", Benchmarking: An International Journal , 21 (6): 884-902.

John, R. and Smith, A. (2014) "Awareness and effectiveness of quality function deployment (QFD) in design and build projects in Nigeria", Journal of Facilities Management, 12 (1): 72-88.

Ferrari F., Emiliani E. (2009) Le competenze e il mercato del lavoro. Un'analisi dei fabbisogni formativi tra scuola e impresa, Carocci, Roma.

Ferrari, F. (2010) Work Performance $=$ Competence $\mathrm{x}$ Motivation. Human Resources Management (November 23, 2010).

Gungor, P. (2011) The Relationship Between Reward Management Sistem and Employee Performance with the mediating Role of Motivation: A Quantitative Study on Global Banks. Procedia Social and Behavioral Science, 24, 1510-1520.

Kavaas, B. \& dysvik, A. (2009) "Perceived Investment in Employee Development, Intrinsic Motivation and Work Performance". Human Resource Management Journal, 19 (8): 217-236.

Lawler E. E , Porter L. W. (1967) "The effect of performance on job satisfaction" Industrial Relations Vol. 7, pp. 20-28.

Proudlove, N.C., Black, S. and Fletcher, A. (2007) "OR and the challenge to improve the NHS: modelling for insight and improvement in in-patient flows", Journal of the Operational Research Society, 58 (2); 145-158.

Recker, J.C. (2014) "Suggestions for the next wave of BPM research: strengthening the theoretical core and exploring the protective belt", Journal of Information Technology Theory and Application , 15 (2): 5-20.

Robinson, S. (2005) "Discrete-event simulation: from the pioneers to the present, what next?", The Journal of the Operational Research Society, 56 (6): 619-629.

Sajuyigbe, A.S. Olaoye, B.O, \& Adeyemi, M. A. (2013) "Impact of Reward on Employees Performance in a Selected Manufacturing Companies in Nigeria". International Journal of Arts and Commerce, 2 (2), 27-32.

Spencer, Lyle M. and Signe M. Spencer. (1993) Competence Work: Model for Superior Perfomance. John Wiley and Sons, Inc.

Stajkovic, A.D. dan Luthans, F. (2003) "Behavioral Management and Task Performancein Organizations ; Conceptual Background, Meta Analysis, and Test of Alternative Models”. Journal International of Personnel Psychology. 56 (20), 155-194.

Trkman, P.(2010) "The critical success factors of business process management", International Journal of Information Management, 30 (2): 125-134.

Van Der Aalst, W.P., Ter Hofstede, A.M. and Weske, M. (2003) "Business process management: a survey", in Van Der Aalst, W.P. and Weske, M. (Eds), Business Process Management, Springer, Berlin, Heidelberg, pp. 1-12. 
Van Herpen, Marco. \& Van Praag, Mirjam. (2005) "The Effects of Performance Measurement And Compensation on Motivation: an Emprical Study". International Journal Economis and Business.

Vergidis, K., Turner, C.J. and Tiwari, A. (2008) "Business process perspectives: theoretical developments vs. real-world practice", International Journal of Production Economics , 114 (1): 91-104.

Vernadat, F. , Shah, L. , Etienne, A. and Siadat, A. (2013) "VR-PMS: a new approach for performance measurement and management of industrial systems", International Journal of Production Research, 51 (23-24): 7420-7438.

Vom Brocke, J., Schmiedel, T., Recker, J., Trkman, P., Mertens, W. and Viaene, S. (2014) "Ten principles of good business process management", Business Process Management Journal , 20 ( 4): 530-548.

Wang, T. , Guinet, A. , Belaidi, A. and Besombes, B. (2009) "Modelling and simulation of emergency services with ARIS and Arena. Case study: the emergency department of Saint Joseph and Saint Luc Hospital", Production Planning \& Control , 20 (6): 484495.

Zhao, Y. , Peng, Q. , Strome, T. , Weldon, E. , Zhang, M. , Chochinov, A. and Al-Mashari, M. (2015) "Bottleneck detection for improvement of emergency department efficiency", Business Process Management Journal , 21 (3): 564-585. 